Kwartalnik Młodych Muzykologów UJ

no. 47 (4/2020), 215-227

DOI 10.4467/23537094KMMUJ.20.049.13922

www.ejournals.eu/kmmuj

(iD) https://orcid.org/oooo-ooo3-1775-488o

\title{
Luiza Zapiór
}

THE UNIVERSITY OF WARSAW

\section{The Music Traditions of the Ashkenazi Jews and Radical Jewish Culture: A Brief Outline of the Definitions and Content of Jewish Music in the Past and Nowadays}

\section{Abstract}

The main purpose of this paper is to describe John Zorn's approach to klezmer music and Jewish music tradition in general. The text has been divided into shorter sections. The first part of the article is dedicated to providing an overview of problems concerning the definition of Jewish music. The second part focuses on analysing klezmer motifs in John Zorn's selected works and Jewish symbols present in the visual component of his recording projects. The last section contains a summary and conclusions.

\section{Keywords}

Jewish music, instrumental music, John Zorn, Radical Jewish Culture, contemporary music 


\section{Introduction}

Jewish music continually attracts the interest of both artists and researchers. Some are driven by the need to understand the past and return to their traditions, while others, who view those traditions from an outsider's perspective, are fascinated by the mystery and otherness. Regardless of motives, this subject continues to provoke thought and discussion - starting with questions concerning definition and origins and ending with various concepts of the place of Jewish music in contemporary reality.

It is the latter aspect of the problem - modern times and the present challenges - that constitutes the main subject of this paper. Selected works by the American composer and instrumentalist John Zorn will provide the context and illustration for this analysis. He was the initiator of the Radical Jewish Culture movement and the founder of Tzadik record label, bringing together musicians who perform and create music inspired by and drawing on the klezmer tradition.

The paper is divided into two parts. The first is an outline of issues regarding definition and research into the history of Jewish music, while the second is devoted to klezmer motifs in selected works by John Zorn, as well as the foundations of the Radical Jewish Culture movement. The problem of the use of Jewish symbols on album covers has also been also tackled.

One of the papers discussing Radical Jewish Culture from the musical perspective is Michael Cuthbert's Free improvisation: John Zorn and the Construction of Jewish Identity through Music, whose author conducts an interesting formal and contextual analysis. The book John Zorn: Tradition and Transgression by John Brackett is also of note. It examines, among other things, the role of Jewish tradition in the compositional output of John Zorn. In another important publication, New York Noise. Radical Jewish Music and the Downtown Scene by Tamar Barzel, the author analyses the activities of the Radical Jewish Culture movement from the musical, sociological, and cultural perspectives. In Polish-language literature, though, this topic has not been discussed at length and is still awaiting in-depth interdisciplinary research.

The aim of this paper is to attract Polish readers' attention to Zorn's work and to the transformations of the traditional music culture of 
Ashkenazi Jews that have taken place in America in recent decades, on the example of the Radical Jewish Culture movement that Zorn created.

\section{Definitions of Jewish Music}

What is Jewish Music? What makes us classify a given melody as Jewish? Is it possible to separate the role of Jewish music from ideological issues? Any attempt to answer these questions provokes constant debates. According to Curt Sachs, Jewish music is 'music by Jews, for Jews, as Jews.' ${ }^{1}$ Even though this definition, presented at the First International Congress of Jewish Music in Paris in 1957, is often quoted, we cannot help noticing its downsides. The national criterion that it proposes fits well into the framework of the Zionist ideology, but causes problems in the context of musicological studies. Alexander Knapp sums up these dilemmas accurately:

Does this statement imply that anything composed not by Jews, not for Jews, not as Jews, would, ipso facto, be not Jewish music? Can we tell, just by listening to Prokofiev's Overture on Hebrew Themes, or to Shostakovich's song cycle From Jewish Folk Poetry, for example, that these works were written by composers who were not Jewish, but who nevertheless felt a deep affinity for the Ashkenazi tradition?

Hugo Weisgall, whose approach seems to be an alternative to Sachs' stance, notes that 'there are no specific, objective musical qualities which make a piece Jewish or not. ${ }^{3}$ Although this sentence does not provide us with an unequivocal answer to our question, it draws attention to the problem of impartiality. One can argue that music has no objective identity in itself. In this context, Judy Cohen's comment

1 J.M. Cohen, 'Jews and Music', Oxford Bibliographies, https://www.oxfordbibliographies.com/view /document/obo-9780199840731/obo-9780199840731-0063.xml, accessed 13 May 2021.

2 A. Knapp, 'Conceptualizing "Jewish Art Music" While Standing on One Leg: A Scholar's Dilemma', Journal of the American Musicological Society, 65 (2) (2012), 565.

3 Knapp, 'Conceptualizing...', 566. 
acquires profound significance. We must be aware, she claims, that when examining Jewish music we always refer to someone else's narrative:

Josef Singer codified the synagogue modes in earnest in $1886 ;[\ldots]$ Abraham Zvi Idelsohn connected them with the Arabic maqam style and provided rules for harmonizing them in the the early twentieth century; [...] Isadore Freed contextualized them within the Western music canon in 1958; and [...] Eric Werner asserted their ancient nature as a determinant for Jewish identity [...]. The way in which scholars think about the topic today relies in large part on the ideology, politics, projects, and arbitrary decisions of those who achieved the status of Jewish music authorities in the past. ${ }^{4}$

One should also note that the existence of a Zionist diaspora in all the continents makes Jewish music diversified, multicultural and, as a result, difficult to define and describe as a whole. There are virtually no written sources, either. Oral transmission of melodies functioned effectively for hundreds of years (the hazzanim did not receive formal music education and did not learn music notation until the mid-nineteenth century). ${ }^{5}$ In folk music, knowledge was universally transmitted in the oral form, and Jewish music was not different from other musical cultures in this respect.

With the advent of the Haskalah and the transformations it proposed, such as greater integration with the non-Jewish population, focusing attention on secular, not only on religious education, and an increased interest in Jewish history, the need to build a secular form of Jewish identity emerged. That period laid the foundations for the musical culture that in the last decades of the nineteenth century would come to be called Jewish music. ${ }^{6}$ Philip Vilas Bohlman discusses at length one of the causes for this phenomenon:

Before modernity $[. .$.$] 'music' was largely vague as an aesthetically$ autonomous object in Jewish society. In a strict sense everything in the synagogue was music - prayer, Torah and Haftorah, cantillation,

4 J.M. Cohen, Whither Jewish Music? Jewish Studies, Music Scholarship, and the Tilt between Seminary and University (2008), 31.

5 P.C. Kim, 'Transmission of Music in the Hebrew Tradition', The Bulletin of Historical Research in Music Education 19 (1) (1997), 44.

$6 \quad$ P.V. Bohlman, Jewish Music and Modernity (2013), xviii. 
ritual and liturgical interjection - therefore it was impossible to limit it to any single category. [...] The cyclical nature of liturgical practices bounded music within ritual and prevented it from flowing over into the temporal world outside the synagogue?

It can therefore be said that Jewish music was 'invented' at one point in history or that it began to exist outside the liturgical context at that time. Undoubtedly, having one's own music is an essential part of national identity, and the last decades of the nineteenth century were a period of the development of Zionism. Regardless of ideological or philosophical issues, however, it can be observed that how Jewish music is defined undoubtedly depends on the definer. Religion, politics, and above all, the ever-changing reality are elements that influence what Jewish music is at any given moment.

\section{From Traditional to Contemporary Jewish Culture: Analysis of Selected Musical and Cultural Themes in John Zorn's Projects}

The Holocaust caused Jewish music to lose many of its continuators after World War II. It is worth mentioning in this context that Jewish immigrants to the United States continued their musical activity already since the pre-war times. They combined their own traditions with elements of musical styles they encountered in North America. In this way, a new kind of expression emerged within Jewish music, whose identity took shape with reference to the US music scene. New Jewish music can hardly be discussed without mentioning the figure of John Zorn, who is an artist committed to its development and to finding a place for that music in the contemporary context. The Tzadik record label, which he founded in 1995, is the largest and most recognisable record company focusing on Jewish music in its present-day versions, frequently perceived as avant-garde. Zorn's oeuvre provides representative examples of how music labelled as Jewish can function in the present-day reality.

No label comparable to Tzadik in terms of scale and profile has been established in Poland and the whole of Europe so far. For this reason, new interpretations of Jewish music, for example from Poland, are

Bohlman, Jewish Music..., xix. 
frequently compared to those of New York's Radical Jewish Culture scene and the Tzadik artists. ${ }^{8}$ Regardless of whether such comparisons are legitimate or not, John Zorn and his activity have played a major role in the rise of new Jewish music.

Zorn became interested in the Zionist tradition in the early $1990 \mathrm{os.}$ At that time, he was already a nearly forty-year-old artist with a well-established position in the world of music. He had experience as both a performer and composer of, among others, jazz and classical music. As he himself stated, the shift towards Jewish culture resulted from his frequent collaborations with musicians of such origin, the anti-Semitism that he encountered while touring with concerts in other countries, and the discovery that he did not belong in Japanese culture, which had been his focus of interest in earlier times. ${ }^{9}$ The artist has Jewish roots himself. The problems of redefining Jewish music and rethinking the directions of its development became important to him:

Tradition, history and the past have always played a strong role in the life of the jews [sic] but it is also important to think about the future. As we grow as a people, it seems natural that our culture should grow along with us. Just as jazz music has progressed from dixieland to free jazz and beyond in a few short decades, and classical music went from tonality to chromaticism, noise and back again, it has occurred to me that the same kind of growth should be possible and is perhaps essential for jewish [sic] music. ${ }^{10}$

The first CD which shows Zorn turning towards his Jewish roots is Kristallnacht, released in 1993. As Tamar Barzel notes, the compositions on that album also demonstrate Zorn's interest in the aesthetics of hardcore rock and modernist composition techniques. As in his previous works, the music seeks to overwhelm the listener with extremely intense experiences, enhanced by correlating the musical material with

8 M. Schray, 'Shofar: Ha-Huncvot (Kilogramm 2013)', CD review, Freejazzblog. com, 8 July 2013, https://www.freejazzblog.org/2013/o7/shofar-ha-huncvot-kilogramm-2013.html, accessed 12 June 2020.

$9 \quad$ M.S. Cuthbert, 'Free improvisation: John Zorn and the Construction of Jewish Identity through Music', in K.K. Shelemay, ed., Studies in Jewish Musical Traditions. Insights from the Harvard Collection on Judaica Sound Recordings (2001), 10.

10 J. Zorn, 'Radical Jewish Culture', Tzadik.com, 2006, http://www.tzadik.com/rjc info.html, accessed 22 June 2019. 
images, titles, and extramusical contents. ${ }^{11}$ The title refers to the pogrom known as the Night of Broken Glass (Germ. Kristallnacht), which took place in Germany on the night of 9-10 November 1938. Kristallnacht is perceived as an event that carried the persecution of Jews into its next, most radical stage, inevitably leading towards the Holocaust.

The musicians featured on Kristallnacht are pianist Anthony Coleman, bassist Mark Dresser, violinist Mark Feldman, trumpeter Frank London, guitarist Marc Ribot, drummer William Winant, and David Krakauer on the clarinet and bass clarinet. The opening piece, 'Shtetl', contains distinct references to the klezmer tradition, fused here with the practice of improvisation and elements of concrete music. The transcriptions below reveal klezmer inclinations in this piece. Frank London's trumpet solo is based on the Mi sheberach mode characteristic of this type of music. There is also rotary movement of the melody (Transcription 1) and the typical repetition of the first (Transcription 2) and the fifth degrees of the scale (Transcription 3 ) at the ends of phrases. The form gets deconstructed in the course of the music through the gradual introduction of dissonances and withdrawal from fixed metre in favour of freedom of expression and free-jazz style. There is also an element of concrete music in the form of an excerpt from Adolf Hitler's speech.

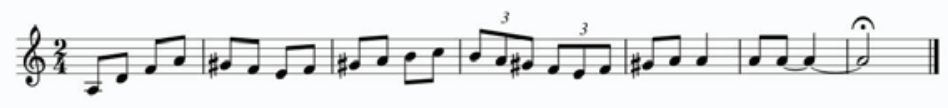

Transcription 1. Shtetl, trumpet solo performed by Frank London. Source: J. Zorn, Shtetl, perf. F. London, in Kristallnacht, Tzadik, New York 1993, 0:01-0:07.

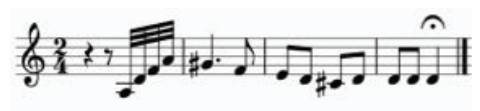

Transcription 2. Shtetl, trumpet solo performed by Frank London. Source: J. Zorn, Shtetl, perf. F. London, in Kristallnacht, Tzadik, New York 1993,0:07-0:14.

${ }^{11}$ T. Barzel, New York Noise: Radical Jewish Music and the Downtown Scene (2015), 87. 


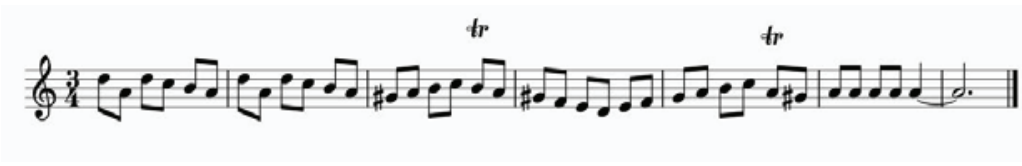

Transcription 3. Shtetl, trumpet solo performed by Frank London. Source: J. Zorn, Shtetl, perf. F. London, in Kristallnacht, Tzadik, New York 1993, 0:15-0:24.

The theme of the Shoah, the use of elements of concrete music, and the tripartite structure corresponding to the three dimensions of time, may evoke associations with Steve Reich's composition Different Trains. ${ }^{12}$ Like Zorn's work, the latter piece is divided into three sections related to three temporal planes, namely - what happened before, during, and after World War Two. Zorn explains the issue of understanding time and history in his work by saying that he wanted to create a composition based on his observations of Jewish experiences, not only of the Holocaust but also of what happened before and afterwards, that is, about the birth of the State of Israel, problems with excessive orthodoxy, today's Jews, and where they are heading. Later, however, he decided to make something that would not be based on a history of pain and suffering, but on the future and on how bright and beautiful it may be. ${ }^{13}$

It should be emphasised that klezmer music was for Zorn only one of many sources of inspiration on this album. The pieces released on Kristallnacht draw, for example, on synagogal music, free-jazz type of expression, concrete music, and the game piece technique, which consists in basing a work of music on composition schemes taken from game theory (the piece titled 'Tikkun'). These works undoubtedly deserve a detailed analysis, which would focus on the use of composition techniques. 'Shtetl', which draws on klezmer music to the greatest extent, is (in the context of the subject of this paper) a representative example of a work inspired by one of the musical trends derived from the rich and varied tradition of Ashkenazi music.

Kristallnacht proved to have been the first step towards achieving another goal: that of presenting such music as a developing and vital part of contemporary Jewish identity and culture. The first of the

12 Cuthbert, 'Free improvisation..., 11.

13 J. Zorn, 'Scene by scene', an interview conducted by L. Blumenfeld, Jazziz, 8 (1999), 12. 
three parts of Masada, composed in 1993, was conceived as a means to this end. It is a collection of short pieces referring to various traditions within Jewish music. The total number of compositions in all the sections of the Masada cycle is 613, that is, precisely the number of mitzvahs distinguished in Judaism; the titles of the works come from Hebrew. Masada is sometimes described as a fusion of klezmer music and free jazz in Ornette Coleman' ${ }^{14}$ performance style. The instrumental line-ups are not specified, nor is there one predefined arrangement. The concept of performance is therefore similar to the interpretation of jazz standards, which, admittedly, impose a particular harmonic pattern and melodic character but leave the rest to the performers. Attention should also be drawn to Zorn's, frequently unnoticed, ventures beyond klezmer style into the world of Sephardic and Arabic music. Masada is thus a collection that shows Jewish music from a variety of angles. Zorn's approach to the role of the performers in the process of interpretation allows him to present it in the way he himself understands and conceives of that music.

Masada was also to offer proof that Jewish music can exist outside the sphere of klezmer music. However, considering the project's reception, it is difficult to demonstrate unequivocally whether this goal has been achieved or not. Zorn notes and emphasises this himself when he says that the only thing that surprises him greatly and is a symbol of musicians' limited perceptions is the way critics have pigeonholed his project: 'Klezmer meets Ornette!' Naturally, there is a klezmer element to it. And of course, Coleman is in it too. But, Zorn claims, the project has also had many other inspirations. ${ }^{15}$

Jewish elements in Zorn's output are not always related to the music itself. The Hebrew titles of the individual pieces and album covers that explore Jewish motifs or refer to the symbolic significance of numbers also contribute to the fact that his works are perceived and classified as Jewish.

An interesting example of the use of numerical symbolism is the piece Sacred Rites of the Left Hand Path, in which John Brackett finds cabbalistic inclinations. The ostinato on which this composition is based is in 13/8 time. According to the rules of gematria, thirteen is the numerical value of the words 'love' (אהבה) and 'one' (אחד). This may

\footnotetext{
S. Rogovoy, The Essential Klezmer (2000), 145.

Zorn, 'Scene by scene', 13.
} 
hint at the religious dimension of the music; in the Jewish tradition, the masculine word for 'one' frequently stands for God, Adonai Echad..$^{16}$ However, it is difficult to determine whether such a reading is in any way related to the composer's actual intentions or should be dismissed as an overinterpretation.

Jewish symbolism also appears on the album covers. Masada Guitars (Figure 1) features hands forming the cabbalistic Tree of Life with its ten Sephirot. The cover of The Unknown Masada (Figure 2) presents a yad with the word (literally 'science, knowledge') in the background, probably symbolising science and wisdom of the Torah. It can be concluded that the symbols presented on the covers and in the titles of compositions do not refer to the musical content of the works themselves. They rather serve to form an appropriate impression in the listeners and bestow authenticity on the presented music.

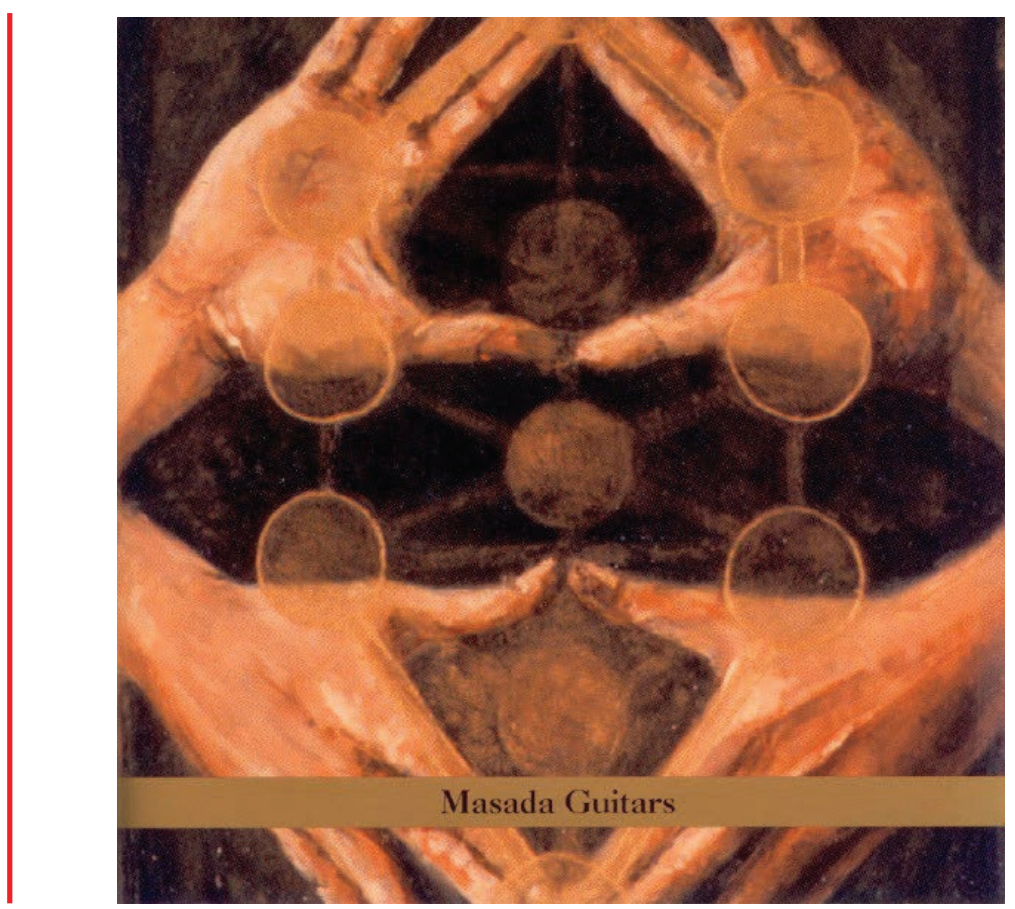

Fig. I. Cover of the album Masada Guitars. Source: http://www.allmusic.com/ album/masada-guitars-mwooo0234597, accessed I6 January 2019.

${ }^{16}$ J. Brackett, John Zorn: Tradition and Transgression (2008), 68. 


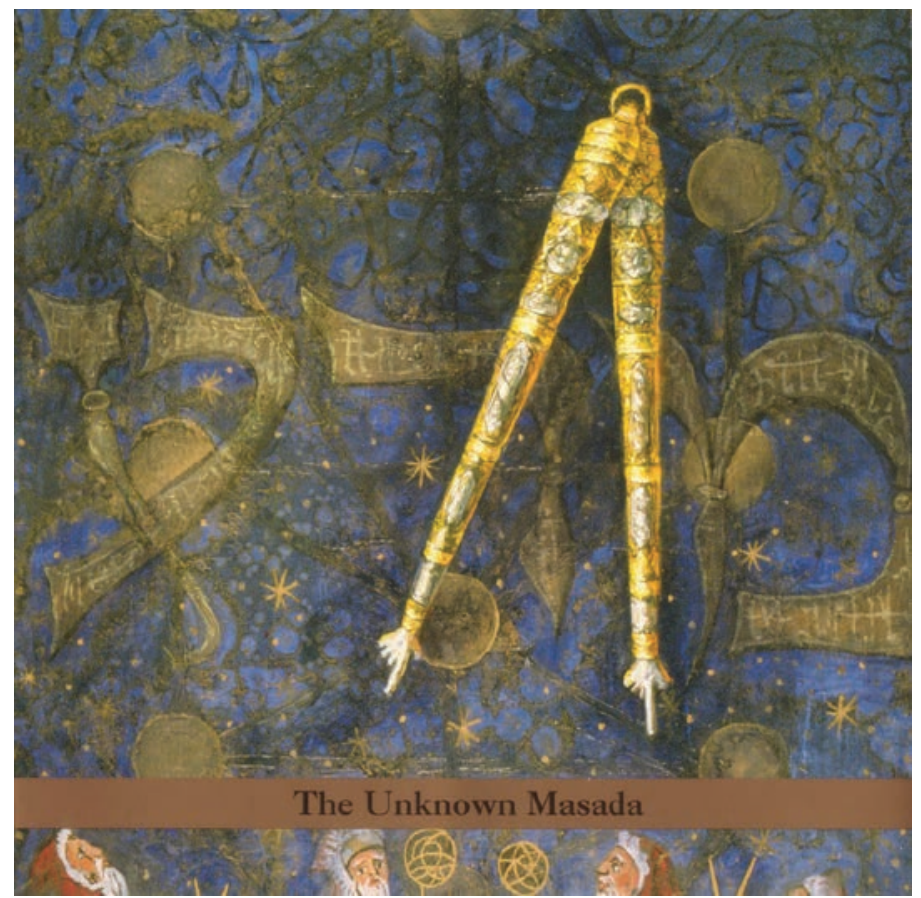

Fig. 2. Cover of the album The Unknown Masada. Source: https://www.discogs. com/John-Zorn-The-Unknown-Masada/release/529218, accessed I6 January 2019.

\section{Summary and Conclusions}

John Zorn's output related to Jewish music can be divided into two stages. The first, associated with the CD Kristallnacht, is a memory of the past: of the tragic period of the Holocaust and the beginnings of the State of Israel. This musical memory alludes to historical events on the one hand, while on the other it is expressed in a modern musical language. This can be interpreted as a foreshadowing of the next stage, represented by Masada, which aimed to look towards the future and bring Jewish music into the new century. Without ignoring the diversity of traditions, this project gave the performers the possibility to discover for themselves what Jewish music can be like.

Zorn has undoubtedly succeeded in capturing, with some of his theories, the indefinable nature of Jewish music. The solution, in this case, is not to establish specific rules, qualities, and conditions to be 
fulfilled, but rather to accept the dynamic and fluid character that is the essence of Jewish music. This approach is a reaction to the complicated realities of Judaic culture after World War Two and to the question what place music should occupy in it. Further analyses of Zorn's compositions drawing on Jewish musical traditions other than klezmer are undoubtedly necessary. Zorn's musical output and his basic tenets have played an essential role in the process of the universalisation of Jewish music, which results in the musical tradition of one particular group becoming a universal source of artistic inspiration. This was aptly summed up by Tamara Sztyma, who paraphrases the discursive definition of Kurt Sachs: '[...] new Jewish music is created today mainly by non-Jews, also for non-Jews, and is becoming part of the universal sphere. ${ }^{3}$

\section{Bibliography}

\section{References}

Barzel, T., New York Noise: Radical Jewish Music and the Downtown Scene (Indiana UP: Bloomington, 2015).

Bohlman, P.V., Jewish Music and Modernity (Oxford University Press: Oxford, 2013).

Brackett, J., John Zorn: Tradition and Transgression (Indiana UP: Bloomington, 2008).

Cohen, J.M., 'Jews and Music', Oxford Bibliographies, https://www.oxfordbibliographies.com/ view/document/obo-9780199840731/obo9780199840731-0063.xml, accessed 13 May 2021.

Cohen, J.M., Whither Jewish Music? Jewish Studies Music Scholarship, and the Tilt Between Seminary and University (Cambridge University Press: Cambridge, 2008).

Cuthbert, M., 'Free improvisation: John Zorn and the Construction of Jewish Identity through Music', in K.K. Shelemay, ed., Studies in

17 T. Sztyma, 'Duma, zabawa i milczenie', interview by I. Świerkocka, Dwutygodnik, 206 (2017), http://www.dwutygodnik.com/artykul/6988-duma-zabawa-i-milczenie, accessed 5 Aug. 2019. 
Jewish Musical Traditions. Insights from the Harvard Collection of Judaica Sound Recordings (Harvard College Library: Cambridge, 2001). Knapp, A., 'Conceptualizing "Jewish Art Music" While Standing on One Leg: A Scholar's Dilemma', Journal of the American Musicological Society, 65 (2) (2012), 557-592.

Kim, P.C., 'Transmission of Music in the Hebrew Tradition: Learning from the Songs of the Synagogue', The Bulletin of Historical Research in Music Education, 19 (1) (1997), 40-51.

Rogovoy S., The Essential Klezmer. A Music Lover's Guide to Jewish Roots and Soul Music, from the Old World and the Jazz Age to the Downtown Avant-Garde (Algonquin Books of Chapel Hill: New York, 2000).

Zorn J., 'Scene by scene', interview by. L. Blumenfeld, Jazziz, 8 (1999), $12-13$.

\section{Internet Sources}

Schray, M., 'Shofar: Ha-Huncvot (Kilogramm, 2013)', CD review, Freejazzblog.com, 8 July 2013, https://www.freejazzblog.org/2013/o7/shofar-ha-huncvot-kilogramm-2013.html, accessed 12 June 2020.

Sztyma, T., 'Duma, zabawa i milczenie', interview by I. Świerkowska, https://www.dwutygodnik.com/artykul/6988-duma-zabawa-i-milczenie.html?print $=1$, accessed 5 August 2019.

Zorn, J., 'Radical Jewish Culture', http://www.tzadik.com/rjc info.html, accessed 22 June 2019. 